\title{
Front Matter: Volume 11652
}

, "Front Matter: Volume 11652," Proc. SPIE 11652, Adaptive Optics and Wavefront Control for Biological Systems VII, 1165201 (9 April 2021); doi: $10.1117 / 12.2596622$

SPIE. Event: SPIE BiOS, 2021, Online Only 


\section{Adaptive Optics and Wavefront Control for Biological Systems VII}

Thomas G. Bifano

Sylvain Gigan

$\mathrm{Na} \mathrm{Ji}$

Editors

6-11 March 2021

Online Only, United States

Sponsored and Published by

SPIE 
The papers in this volume were part of the technical conference cited on the cover and title page. Papers were selected and subject to review by the editors and conference program committee. Some conference presentations may not be available for publication. Additional papers and presentation recordings may be available online in the SPIE Digital Library at SPIEDigitalLibrary.org.

The papers reflect the work and thoughts of the authors and are published herein as submitted. The publisher is not responsible for the validity of the information or for any outcomes resulting from reliance thereon.

Please use the following format to cite material from these proceedings:

Author(s), "Title of Paper," in Adaptive Optics and Wavefront Control for Biological Systems VII, edited by Thomas G. Bifano, Sylvain Gigan, Na Ji, Proceedings of SPIE Vol. 11652 (SPIE, Bellingham, WA, 2021) Seven-digit Article CID Number.

ISSN: 1605-7422

ISSN: 2410-9045 (electronic)

ISBN: 9781510641396

ISBN: 9781510641402 (electronic)

Published by

SPIE

P.O. Box 10, Bellingham, Washington 98227-0010 USA

Telephone +1 3606763290 (Pacific Time) · Fax +1 3606471445

SPIE.org

Copyright (c) 2021, Society of Photo-Optical Instrumentation Engineers.

Copying of material in this book for internal or personal use, or for the internal or personal use of specific clients, beyond the fair use provisions granted by the U.S. Copyright Law is authorized by SPIE subject to payment of copying fees. The Transactional Reporting Service base fee for this volume is $\$ 21.00$ per article (or portion thereof), which should be paid directly to the Copyright Clearance Center (CCC), 222 Rosewood Drive, Danvers, MA 01923. Payment may also be made electronically through CCC Online at copyright.com. Other copying for republication, resale, advertising or promotion, or any form of systematic or multiple reproduction of any material in this book is prohibited except with permission in writing from the publisher. The CCC fee code is $1605-$ $7422 / 21 / \$ 21.00$.

Printed in the United States of America by Curran Associates, Inc., under license from SPIE.

Publication of record for individual papers is online in the SPIE Digital Library.

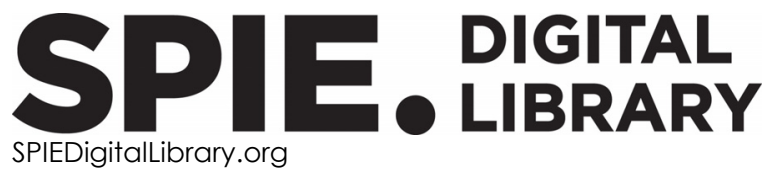

Paper Numbering: Proceedings of SPIE follow an e-First publication model. A unique citation identifier (CID) number is assigned to each article at the time of publication. Utilization of CIDs allows articles to be fully citable as soon as they are published online, and connects the same identifier to all online and print versions of the publication. SPIE uses a seven-digit CID article numbering system structured as follows:

- The first five digits correspond to the SPIE volume number.

- The last two digits indicate publication order within the volume using a Base 36 numbering system employing both numerals and letters. These two-number sets start with $00,01,02,03,04$, 05, 06, 07, 08, 09, 0A, OB ... 0Z, followed by 10-1Z, 20-2Z, etc. The CID Number appears on each page of the manuscript. 


\section{Contents}

\section{SHAPED BEAMS FOR UGHTSHETTAND STRUCTURED IUUMINATION MIC ROSC OPY}

1165207 Enhanced field-of-view high-resolution lattice light sheet mic rosc opy with phased anay beam formers [11652-15]

11652 OA Structured illumination microsc opy with direct wavefront sensing [11652-18]

WAVERONTSHAPING DEVICES

11652 OF Experiments of scene-based adaptive optics with differential sensing technique [11652-21]

IMAGING NEURALCONNEC TIVITY AND FUNCTION DEEP IN BRAIN TISSUE

11652 ol Rapid 3D imaging of a seizure model in zebrafish using an electrically tunable lens with adaptive optics comection [11652-10]

11652 0] Adaptive three-photon microscopy for fine structure imaging deep in the mouse brain [11652-11]

IMAGING WTH MULTIMODE RBERS

11652 OL Multimode fiber projector with neural networks [11652-13]

POSTER SESSON

$1165200 \quad$ Integrated optical phased arrays for optical trapping [11652-22] 
Proc. of SPIE Vol. 11652 1165201-4

\section{Downloaded From: https://www.spiedigitallibrary.org/conference-proceedings-of-spie on 25 Apr 2023
Terms of Use: https://www.spiedigitallibrary.org/terms-of-use}

